UKRAINIAN RAILWAY INFRASTRUCTURE: STATIONS CLOSURE EFFECTS ЗАЛІЗНИЧНА ІНФРАСТРУКТУРА УКРАЇНИ: ЕФЕКТ ЗАКРИТТЯ СТАНЦІЙ

\section{UDC 656.2}

DOI: https://doi.org/10.32843/infrastruct50-12

\author{
Chornopyska Nataliya \\ PhD, Associate Professor \\ at Department of Marketing and Logistics \\ Lviv Polytechnic National University \\ Stasiuk Kateryna \\ PhD Student \\ Lviv Polytechnic National University
}

\begin{abstract}
The article considers railway infrastructure optimization problem, which is included in the state transport strategy. The question of numerous stations closing was defined as acute at the current stage of Ukrainian railway transport development. Particular station being included in the list of inactive and considered a subject for closure activities has been thoroughly studied. The economic part of activities for this station has been analyzed, economic results have been calculated. Inactive stations and railway infrastructure lines closure effect has been complemented by social effect. Inactive stations closure consequences have been established and detailed by the breadth of coverage: single, local, regional, state, and global. Railway network reduction influence on the railway logistic potential has been analyzed. It has been proved that extensive railway infrastructure can be a competitive advantage for country's economy. An effective financing mechanism for the railway infrastructure in general and the system of state support for inactive stations and railway lines operation necessities have been proved.

Key words: railway infrastructure, inactive stations, railway network, logistics potential, socioeconomic effect.
\end{abstract}

В статье рассмотрена проблема оптимизации железнодорожной инфраструктуры, которая предусматривается транспортной стратегией страны. Установлено, что на современном этапе развития железно- дорожного транспорта Украины, остро cmoum вопрос закрытия многочисленного количества станций. Основательно исследована деятельность одной из станций, находящихся в списке малодеятельных и подлежащих закрытию. Проанализировано экономическую сторону деятельности такой станции, рассчитано экономический результат. Экономический эффрект закрытия малодеятельных станций и линий железнодорожной инфраструктуры дополнен социальным эфффектом. Установлено последствия закрытия малодеятельных станций и детализировано их по широте охвата: точечные, местные, областные, региональные, государственные, глобальные. Проанализировано влияние сокращения железнодорожной сети на логистический потенциал железной дороги. Доказано, что разветвленная железнодорожная инсрраструктура может быть конкурентным преимуществом экономики страны. Установлена необходимость внедрения действенного механизма финансирования железнодорожной инфрраструктуры в целом и системы государственной поддержки по эксплуатации малодеятельных станций и линий железной дороги.

Ключевые слова: железнодорожная инфрраструктура, малодеятельные станции, железнодорожная сеть, логистический потенциал, социально-экономический эффрект.

У статті розглянуто проблему оптимізації залізничної інфрраструктури, що передбачена транспортною стратегією країни. Виділено дві основні фрункції, які виконує наявна розгалужена залізнична мережа - суспільні цілі та економічний розвиток регіону. Проаналізовано, що для створення інтегрованого європейського транспортного простору зараз не вистачає такої розгалуженості мережі, саме тому для української залізниці слід не втрачати такої своєї конкурентної переваги на шляху до євроінтеграції. Встановлено, що на сучасному етапі розвитку залізничного транспорту України, гостро стоїть питання закриття численної кількості станцій. Грунтовно досліджено діяльність однієї із станцій, що знаходиться в списку малодіяльних і підлягає закриттю. Проаналізовано економічну сторону діяльності такої станції, розраховано економічний результат. Економічний ефект закриття малодіяльних станцій та ліній залізничної інсрраструктури доповнено соціальним ефектом. Встановлено наслідки закриття малодіяльних станцій залізниці, а саме: збільшення безробіття, занепад цілих поселень, погіршення якості життя дотичного населення, недоотримання коштів у місцеві бюджети, посилення урбанізації, занепад суміжних та взаємодоповнюючих галузей, погіршення стану екології через збільшення навантаження на автомобільний транспорт, погіршення інвестиційного клімату, посилення трудової міграції, зменшення перспектив участі у міжнародних проектах тощо. Деталізовано наслідки за широтою охоплення: точкові, місцеві, обласні, регіональні, державні, глобальні. Проаналізовано вплив скорочення залізничної мережі на логістичний потенціал залізниці. Доведено, що розгалужена залізнична мережа може бути конкурентною перевагою економіки країни. Наявність розгалуженої залізничної інфрраструктури в Україні - це потенційні зони зростання економіки в майбутньому. Обгрунтовано важливість збереження цього важливого компоненту логістичного потенціалу залізниці та країни загалом. Встановлено необхідність впровадження дієвого механізму фрінансування залізничної інфрраструктури загалом та системи державної підтримки щодо експлуатації малодіяльних станцій та ліній залізниці.

Ключові слова: залізнична інфрраструктура, малодіяльні станції, залізнична мережа, логістичний потенціал, соціально-економічний ефеект.

Problem formulation. Ukrainian railway should be considered as a universal means of transportation and the engine for the entire economy. An extensive railway network is a significant competitive advantage for the transport system and the country as a whole. Two main functions fulfilled by the extensive network model include social goals and economic development of the region. Such an extensive network could aid greatly in integrated European transport space creation. That is why Ukrainian Railways should not lose such a competitive advantage on the European integration path. The modern railway freight industry of Ukraine is in a critical state demonstrating lasting recession dynamics. A number of problems have hit the railway, but one of them, namely the problem of redundant railway infrastructure of JSC "Ukrainian Railways", is considered new and thus requires a detailed study. About $80 \%$ of all freight traffic is performed by $30-40 \%$ of existing freight stations [1]. The rest perform a relatively small amount of work causing JSC "Ukrainian Railways" to confidently position them as unprofitable. As of March 21, 2020, 320 stations throughout the railway network of Ukraine are listed as inactive [2]. Physical inactive stations closure can provide only temporary positive results for the railway, but concerning the Ukrainian 
economy - such a drastic reduction of railway network will bring a negative economic and social effect. Thus a problem of determining the strategically necessary railway infrastructure for Ukraine is being introduced and its sources of funding are to be developed. According to previous authors research, the main stakeholder - that is Ukrainian government - view on the railway network has yet to be formed. Extensive railway infrastructure can be a competitive advantage for Ukrainian economy if not only economic but also a social effect is considered.

Analysis of recent research and publications. Modern researches concerning a problem decision for inactive railway transport sections are considered actual in the scientific space. There is a study of Professor Kulaiev U.F. describing current problems for inactive areas and stations [3; 4]. The problems requiring immediate solution are emphasized: an effective train traffic organizing methods development, especially for extreme areas; transportations development forecasting taking into account the factors influencing them; the legal framework update for regulating railways, government agencies and NGOs interaction; a mechanism of closing, conservation or privatization development for inactive sections and railway lines; transportation and individual operation costs calculation methods revision and improvement for the transportation process in inactive areas; a system of state support for the operation of such lines development. World experience in the operation of inactive sections study of Professor Zorin O.I. is especially important [5]. International experience analysis proved that inactive areas existence on international railways is also an urgent problem, having several solutions. Professor proposed to introduce a software and hardware microprocessor system complex MSDC "CASCADE" for dispatching centralization in low-activity sections in order to increase the efficiency of freight and passenger traffic management. There are radically different methods of solving this problem according to international experience: sections closure, lease, transfer to private management, operating methods simplification. Professor H.D. Eitutis also offered his recommendations on solving the problems of inactive lines - categorization of stations according to the criteria of load intensity and train speed [6] Author proved that economic activity improvement for railways in the period of reform depends on multidisciplinary components efficiency, including dead-end stations of inactive sections. Additional fees for dead-end stations make up almost 4\% of the total rail freight fee. A method has been developed to determine the operation expediency for dead-end stations of inactive sections or their closure in general as separate points on SouthWestern Railway example. Scientist Kyrylenko O.M. developed a conceptual approach for management system building for inactive sections in the structure of JSC "Ukrainian Railways" on the basis of optimal, balanced organizational management model [7]. The researcher proposed a methodical approach for transportation activities effectiveness assessment in inactive sections, taking into account the quality indicators system and being based on the forecast. Also the railway infrastructure development areas were structured: modernization, investment attraction, public-private partnership. The station inactivity problem is relevant, but insufficiently studied and thus requiring more detailed recommendations.

Purpose and objectives for the study. The main purpose of the article is to prove or disprove the hypothesis: whether railway infrastructure is a competitive advantage or burden for the Ukrainian economy. The key tasks to be solved in the article include: to analyze economic and social side of a station operation and justify economic and social effect of closure with the help of economic and mathematical calculations; to build a hierarchy of consequences for inactive railway stations closure; to analyze railway network reduction consequences for the logistics potential; to develop recommendations for individual stations inactivity problem solving.

Main research material presentation. Economic and mathematical calculations were performed to test hypothesis of the study, on the basis of one of the stations in the list of inactive.

Economic side for the station operation is to be considered. General information considering the station cargo operations for 2017: the station shipped 76 cars; senders paid 1,615,137.20 UAH to Ukrainian Railways account for operations related to sending these cars; the elevator paid 57,207.24 UAH for access tracks maintenance, which are on the balance of Ukrainian Railways; costs required for the station to remain capable of carrying out cargo operations do not exceed 271,023.95 UAH including VAT.

It is important to specify the elevator parameters: simultaneous grain storage capacity - 17,000 tons (or 261 cars); supply front - 11 grain wagons; shipment capacity - up to 22 cars per day.

Parameters of the focused station: the station processing capacity limit - 4 cars per day; railway weight for cars weighing availability; receiving and delivery track, which can accommodate 48 grain wagons at once.

Detailed analysis for the income items and expenses of the station as a result of cargo operations with the elevator in 2017 is provided in Table.

The data provided above can be summarized into obvious calculations proving effectiveness of this station; analyzing by income - costs, we get an economic result of $1401320,49 \mathrm{UAH}$. It is possible that in the context of one station such a result is not considered as effective, but the station operation is obviously profitable. 
Analyzed station Revenue and expenditure items in 2017

\begin{tabular}{|l|l|c|}
\hline Reporting article & \multicolumn{1}{|c|}{ Detailed description } & $\begin{array}{c}\text { Sum, } \\
\text { UAH including VAT }\end{array}$ \\
\hline Revenue & Station services, including : & 252581,60 \\
\hline & cars supply and removal & 99537,84 \\
\hline & shunting work & 59529,84 \\
\hline & freight cars and containers usage & 43603,80 \\
\hline & free rate services & 3979,58 \\
\hline & non-compliance with plan fines & 3771,72 \\
\hline & Other & 42158,82 \\
\hline & Railway tariff from Havrylivka station to the destination station & 1362555,60 \\
\hline & Driveway maintenance & 57207,24 \\
\hline & & $\mathbf{1 6 7 2} \mathbf{3 4 4 , 4 4}$ \\
\hline & $\begin{array}{l}\text { Commercial agent salary (including taxes and maximum additional } \\
\text { Charges) }\end{array}$ & 147035,76 \\
\hline & Workplace maintenance & 12000 \\
\hline & Weight maintenance & 111988,19 \\
\hline
\end{tabular}

Source: grouped by authors on the basis of [8]

As of March 20, 2020, 320 stations were declared inactive and requiring closure. If the same result was assumed for all of these stations, the profitability of these stations would be equal to $320 * 1672344,44=$ 535, 15 million UAH accordingly.

It should be noted that only direct costs were taken into account in provided calculations, and capital costs for network maintenance were not considered. The reason for it - this issue is not yet fully regulated. In future, this particular article will be decisive in calculating the self-sufficiency of inactive stations.

European countries experience proves that costly railway infrastructure is a common feature of the EU market, and is financed from the state budgets of respective countries, taking into account also the social component of the problem.

It is not just about economic losses, social losses should also be considered.

Let us consider the social side of the station. Historically, the availability of a railway network has been the basis for settlements emergence, enterprises opening and infrastructure growth around it. Accordingly, in these regions, enterprises that interact with the railway and the railway itself is the main or even only reliable local employer and budgetgenerating element. The aim for a dense railway network development was to unite the whole country through environmentally friendly and safe transport and ensure accessibility to the most remote parts of the country.

Station closure social effect:

Some social effect aspects could be evaluated using simple mathematical calculations. About 10 people work at the average intermediate station. As for elevators or other local small or medium-sized businesses, the number of employees can reach up to 100 people. We need to understand that a hundred employees should be considered as hundred families. As 320 stations are recognized as inactive, about 32 thousand families should be considered at risk. Economically active population after these stations closure decision is going to be left alone with their problems.

Eliminating even one railway link has great economic, social and logistical consequences.

Inactive railway stations closure consequences were summarized into a hierarchy.

Railway network reduction consequences in detail:

1. Single - railway assets value reduction; loss (bankruptcy) of the station main customers (elevators, forestry, farms and other local small and medium businesses); station thefts; unemployment increase; deterioration of life quality for the population concerned;

2. Local - decline of budget-forming enterprises; underfunding for local budgets; entire settlements decline (village, urban-type settlement);

3. Regional - roads load increase; urbanization increase; unemployment increase; negative impact on the socio-economic situation of the region;

4. State - losses for those industries served by the railway (e.g. agricultural and other industries); railway industry losses; environment deterioration due to road freight traffic increase; social tensions in the state increase; urbanization through job search in cities; unemployment increase; population life quality deterioration; logistics potential reduction for the country; cargo flow reduction; rail freight profits reduction; negative consequences for Ukraine's economy in future;

5. Global - exports reduction for those industries served by rail (e.g. for agricultural industry due to late export of agricultural products); investment 
climate deterioration; labor migration strengthening; international projects prospects reduction (e.g. «New Silk Road»).

Particular attention should be paid to the logistical consequences. In their previous studies [9], authors explored the logistical potential of railway transport enterprises, depicted it as a holistic system of indicators and identified all the relationships within it. As for the logistical consequences of railway network reduction, the logistic potential of the railway as an industry will be affected. The logistic potential of the railway is formed by enterprises that provide operational activities and technical components (nodes, networks). Railway stations and network belong to the technical component. Technical and technological support state, in particular rolling stock in operation numbers, active railway stations and terminals number, modern information technologies affect actual possibility of transportation, their intensity and the maximum possible distances for transportation. Railway network reduction consequences on the logistics potential of the railway and its elements are summarized in a table.

Table 2

Station closure impact

on the logistics potential of the railway

\begin{tabular}{|c|c|c|c|}
\hline Component & Part & Indicator & Impact \\
\hline \multirow{4}{*}{$\begin{array}{c}\text { Technical } \\
\text { component }\end{array}$} & \multirow{3}{*}{ Network } & Branching & $\downarrow$ \\
\cline { 3 - 4 } & \multirow{4}{*}{ Nodes } & Length & $\downarrow$ \\
\cline { 3 - 4 } & Quality & 0 \\
\cline { 3 - 4 } & Number & $\downarrow$ \\
\cline { 3 - 4 } & Bandwidth & $\downarrow$ \\
\cline { 3 - 4 } & $\begin{array}{c}\text { Technical equipment } \\
\text { technical equipment }\end{array}$ & 0 \\
\hline \multicolumn{2}{|l|}{ Railway logistics potential } & $\downarrow$ \\
\hline
\end{tabular}

Note: $\uparrow$ - indicator increase; $\downarrow$ - indicator decrease; 0 - difficult to be predicted.

Source: author's own elaboration

The main purpose for stations closure is costs reduction, but as mentioned above, this effect will not be achieved. Logistical consequences include reduction in branching and length of the network, nodes number and bandwidth. In general, this situation has a negative impact on the railway logistics potential.

Thus, elimination of such a seemingly "inactive" railway part in future will cause global economic, social and logistical consequences for the entire coordinated railway system of the country.

Conclusions on the basis of the study. An extensive railway network presence is a potential zone of economic growth in future for Ukraine. It is necessary to preserve this important logistics potential component for the railway and the country as a whole. The most urgent tasks include mechanism for

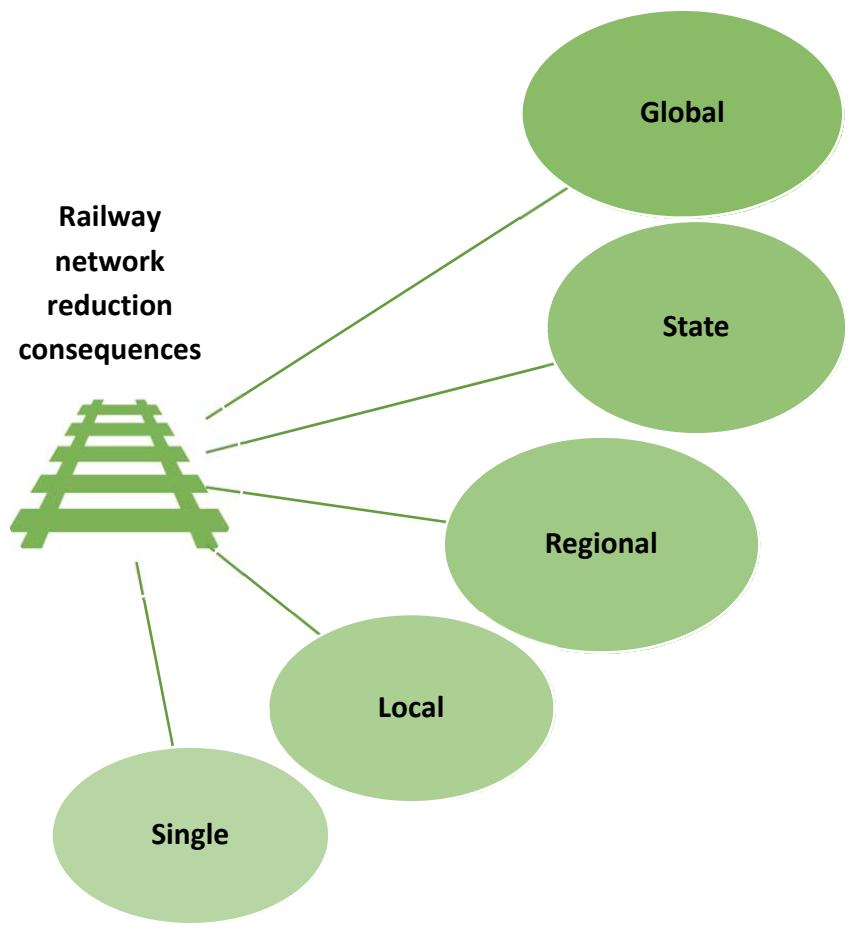

Figure 1. Railway network reduction consequences

Source: author's own elaboration

financing the railway infrastructure and tariff system development. Access fees should include not only the direct costs of infrastructure operator, but also the indirect costs and capital costs of its maintenance and upkeep. It is obvious that inactive stations future will depend greatly on the amount of possible funding from the state budget. According to world experience, without state support the railway network is being constantly reduced.

\section{REFERENCES}

1. Ukrainian railways integrated report (Annual Report) (2018). Available at: https://pbcc.com.ua/dow/2018. pdf (accessed 15 September 2020).

2. Yak AT «Ukrzaliznytsia» pyliaie hilku, na yakii sydyt [How is it that JSC "Ukrainian Railways" saws the branch it is sitting on]. Available at: https://www.ukrinform.ua/rubric-economy/2830750-ak-at-ukrzaliznicapilae-gil-ku-na-akij-sidit.html (accessed 17 September 2020).

3. Kulaiev U.F. (2014) Ekonomika zaliznychnoho transportu: navch. posibn [Railway transport economics: tutorial]. Dnipro: Dnipro National University of Railway Transport. (in Ukrainian)

4. Kulaiev U.F., Korzh V.H., Burleva A.U. (2007) Problemy ekspluatatsii malodiialnykh linii ta dilianok zaliznychnoho transportu Ukrainy [Inactive lines and sections operation problems of Ukrainian railway transport]. Ukrainian railways, no. 28, pp. 28-31 pp.

5. Zorina O.I. (2011) Orhanizatsiino-ekonomichni metody zabezpechennia efektyvnosti vykorystannia dilianok z malymy obsiahamy perevezen [Organiza- 
tional and economic methods for areas with small volumes of traffic usage efficiency ensuring]. Economics and Industry Bulletin, no. 35,pp. 61-63 pp. (in Ukrainian)

6. Eitutis H.D. (2011) Poriadok vyznachennia efektyvnosti roboty tupykovykh stantsii malodiialnykh dilnyts [Efficiency determining procedure for dead-end stations of inactive sections]. All-Ukrainian scientific-practical conference «Problems of economy, ecology and law management concerning transport complex of Ukraine development» materials. Odessa: IMPEER NASU, pp. 103-107 pp. (in Ukrainian)

7. Kyrylenko O.M. (2018) Zabezpechennia efektyvnoho funktsionuvannia malodiialnykh dilnyts PAT «Ukrzaliznytsia» [Effective functioning of inactive sections of JSC "Ukrainian Railways" ensuring]. Dissertation for the Doctor of Economics degree. Dnipro, pp. 229-245 pp.

8. Chy naspravdi 301 zaliznychna stantsiia malodiialna ta zbytkova [Is the 301 railway station really inactive and unprofitable]. Available at: https://agroportal.ua/ ua/views/blogs/deistvitelno-li-301zheleznodorozhnayastantsiya-malodeyatelnaya-i-ubytochnaya/ (accessed 17 September 2020).

9. Chornopyska N., Stasiuk K. (2019) Logistics potential calculation method for enterprise.Proceedings of the 10th International Conference on Applied Economics Contemporary Issues in Economy: Entrepreneurship and Management, 18-25. DOI: https://doi.org/ 10.24136/eep.proc.2019.4.

\section{БІБЛІОГРАФІЧНИЙ СПИСОК:}

1. Інтегроваий звіт AT «Укрзалізниця». URL: https://pbcc.com.ua/download/uz-2018.pdf (дата звернення: 15.09.2020)

2. Як АТ «Укрзалізниця» пиляє гілку, на якій сидить. URL: https://www.ukrinform.ua/rubric-economy/ 2830750-ak-at-ukrzaliznica-pilae-gilku-na-akij-sidit.html (дата звернення: 17.09.2020)

3. Кулаєв Ю.Ф. Економіка залізничного транспорту: навч. посібн. Дніпропетровськ : Дніпропетровський національний ун-т залізничного транспорту ім. акад. В. Лазаряна, 2014. 480 с.

4. Кулаєв Ю.Ф., Корж В.Г., Бурлева А.Ю. Проблеми експлуатації малодіяльних ліній та ділянок залізничного транспорту України. Залізничний транспорт України. 2007. № 28. С. 28-31.

5. Зоріна О.І. Організаційно-економічні методи забезпечення ефективності використання ділянок 3 малими обсягами перевезень. Вісник економіки і промисловості. 2011. № 35. С. 61-63

6. Ейтутіс Д.Г. Порядок визначення ефективності роботи тупикових станцій малодіяльних дільниць. Матеріал Всеукраїнської науково-практичної конференції «Проблеми управління економіки, екології та права щодо розвитку транспортного комплекс України». Одеса : ІПРЕЕД НАН України. 2011. С. 103-107.

7. Кириленко О.М. Забезпечення ефективного срункціонування малодіяльних дільниць ПАТ «Укрзалізниця». Дисертація на здобуття нукового ступеня доктора економічних наук. Дніпро. 2018. C. 229-245.

8. Чи насправді 301 залізнична станція малодіяльна та збиткова? URL: https://agroportal.ua/ua/ views/blogs/deistvitelno-li-301-zheleznodorozhnayastantsiya-malodeyatelnaya-i-ubytochnaya/ (дата звернення: 15.09.2020)

9. Chornopyska N., Stasiuk K. Logistics potential calculation method for enterprise/ Proceedings of the 10th International Conference on Applied Economics Contemporary Issues in Economy: Entrepreneurship and Management. 2018. P. 18-25. DOI: https://doi.org/ 10.24136/eep.proc.2019.4. 